\title{
On modeling and analyzing barley malt data in different years
}

\author{
Iwona Mejza' ${ }^{1}$, Katarzyna Ambroży-Deregowska ${ }^{1}$, Jan Bocianowski ${ }^{1}$, \\ Józef Błażewicz $^{2}$, Marek Liszewski ${ }^{3}$, Kamila Nowosad ${ }^{4}$, Dariusz Zalewski ${ }^{4}$ \\ ${ }^{1}$ Department of Mathematical and Statistical Methods, Poznań University of Life Sciences, \\ Wojska Polskiego 28, 60-637 Poznań, Poland, e-mails: iwona.mejza@up.poznan.pl; \\ katarzyna.ambrozy@up.poznan.pl; jan.bocianowski@up.poznan.pl \\ ${ }^{2}$ Department of Fermentation and Cereals Technology, Wrocław University of Environmental and \\ Life Sciences, Chełmońskiego 37, 51-630 Wrocław, Poland, e-mail: jozef.blazewicz@upwr.edu.pl \\ ${ }^{3}$ Institute of Agroecology and Plant Production, Wrocław University of Environmental and Life \\ Sciences, Grunwaldzki 24A, 53-363 Wrocław, Poland, e-mail: marek.liszewski@upwr.edu.pl \\ ${ }^{4}$ Department of Genetics, Plant Breeding and Seed Production, Wrocław University \\ of Environmental and Life Sciences, Grunwaldzki 24A, 53-363 Wrocław, Poland, \\ e-mails: kamila.nowosad@upwr.edu.pl; dariusz.zalewski@upwr.edu.pl
}

\section{SUMMARY}

\begin{abstract}
The main purpose of this study was the model fitting of data deriving from a three-year experiment with barley malt. Two linear models were considered: a fixed linear model with fixed effects of years and other factors, and a mixed linear model with random effects of years and fixed effects of other factors. Two cultivars of brewing barley, Sebastian and Mauritia, six methods of nitrogen fertilization and four germination times were analyzed. Three quantitative traits were observed: practical extractivity of the malt, malting productivity, and a quality coefficient $\mathrm{Q}$. The starting point for the statistical analyses was the available experimental material, which consisted of barley grain samples destined for malting. The analyses were performed over a series of years with respect to fixed or random effects of years. Due to the strong differentiation of the years of the study and some significant interactions of factors with years, annual analyses were also carried out.
\end{abstract}

Key words: complete randomized design, fixed linear model, mixed linear model, Tukey's HSD test, brewing barley, extractivity, malt, malting productivity, quality coefficient

\section{Introduction}

The choice of an experimental design suitable for the research material is an important issue when modeling data from an experiment repeated in a given 
locality for several years. The analysis of such a series usually uses a mixed linear model, in which it is necessary to determine the type of individual effects (fixed or random). Fixed effects represent the levels of a set of precise hypotheses of interest in the research. They are the only levels about which one would want to make inferences. In the case of random effects the levels that are chosen represent a random selection from a much larger population of equally usable levels. The recognition of certain effects as fixed and others as random affects the properties and shape of the model's variance and covariance structure, and thus the method of statistical analysis.

There are many reports in the literature in which the modeling of data from experiments is considered. Many statistical methods, such as one- or multivariable analysis of variance and others for various experimental projects, have been discussed (see e.g. Caliński, 1967; Caliński et al., 2006; Bocianowski and Nowosad, 2015; Mejza, 1999; Ambroży and Mejza, 2012).

In this study, in view of the subject of research, which was brewery barley malts, a one-step approach was used. A four-way completely randomized (CR) design was used for a series of experiments over three years, and a three-way CR design was used in one-year experiments. More on the choice of model for the experiment can be found in section 3. In section 2 the biological aspects of the experiment are described.

\section{Material and methods}

The experimental material consisted of barley grain originating from a field experiment performed in the years 2008-2010, at the Agricultural Research Station in Pawłowice near Wrocław $\left(51^{\circ} 09^{\prime} \mathrm{N}, 17^{\circ} 06^{\prime} \mathrm{E}\right)$, prepared for processing in a malt-house. This experiment was conducted in a split-block design (in three blocks) with two factors: methods of nitrogen fertilization with doses of $(\mathrm{kg} \mathrm{N}$. ha $\left.^{-1}\right)$ 0, 20, 40, 60, 60 (40+20I), 60 (40+20II); and the cultivars Sebastian and Mauritia. Nitrogen fertilization was applied preplant and top-dressing (divided doses) at two stages of growth: I - at the end of tillering (BBCH29), and II - at the second node stage (BBCH32). The grain was fractionated by means of Vogel screens, and contaminations and damaged grains were removed. After a period of dormancy, grain with fractions of $>2.5 \mathrm{~mm}$ was used to produce 3-, 4-, 5- and 6- 
day Pilsner-type malts under laboratory conditions (third factor). From the malts, congress worts were obtained. The results of the analysis were compared with standard values recommended by the EBC (European Brewing Convention). Evaluation of agrotechnical influence was performed with the use of the Kolbach index, a synthetic factor of protein compound conversion in grain, malts and worts (see Błażewicz and Liszewski, 2003; Błażewicz et al., 2007, 2011, 2013; Liszewski et al., 2012).

Weather conditions play a significant role in the analysis of the experiment. These are presented in Table 1. A detailed description of the weather conditions in the individual years of this study (2008-2010) was given by Liszewski et al. (2012).

Table 1. Weather conditions and hydrothermic indexes

\begin{tabular}{|c|c|c|c|c|c|c|c|c|c|c|c|}
\hline \multirow[b]{2}{*}{ Month } & \multicolumn{4}{|c|}{ Temperature $\left({ }^{\circ} \mathrm{C}\right)$} & \multicolumn{4}{|c|}{ Rainfalls (mm) } & \multicolumn{3}{|c|}{ Sielaninov's index K } \\
\hline & 2008 & 2009 & 2010 & $\begin{array}{l}1981- \\
2010 \\
\end{array}$ & 2008 & 2009 & 2010 & $\begin{array}{c}1981- \\
2010 \\
\end{array}$ & 2008 & 2009 & 2010 \\
\hline III & 4.6 & 4.6 & 4.2 & 3.8 & 33.0 & 48.3 & 44.9 & 31.7 & 2.31 & 3.39 & 3.45 \\
\hline IV & 8.9 & 12.0 & 9.3 & 8.9 & 87.1 & 30.9 & 45.4 & 30.5 & 3.27 & 0.86 & 1.62 \\
\hline $\mathrm{V}$ & 14.3 & 14.2 & 12.7 & 14.4 & 37.3 & 67.6 & 140.7 & 51.3 & 0.84 & 1.53 & 3.57 \\
\hline VI & 18.8 & 15.8 & 17.9 & 17.1 & 36.5 & 141.7 & 32.9 & 59.5 & 0.65 & 3.00 & 0.61 \\
\hline VII & 19.8 & 19.5 & 21.4 & 19.3 & 65.6 & 134.2 & 78.6 & 78.9 & 1.06 & 3.24 & 1.19 \\
\hline VIII & 18.8 & 19.3 & 18.9 & 18.3 & 94.0 & 53.5 & 61.5 & 61.7 & 1.61 & 0.89 & 1.86 \\
\hline $\begin{array}{c}\text { Mean/Sum } \\
\text { III-VIII }\end{array}$ & 14.2 & 14.2 & 14.1 & 13.6 & 353.5 & 476.2 & 404.0 & 313.6 & - & - & - \\
\hline
\end{tabular}

Thus, we assume for simplicity that we have three factors: nitrogen fertilization (A), cultivars (B) and germination time (C). The study considered their influence on the practical extractivity of the malt, the malting productivity, and a quality factor $\mathrm{Q}$. The chemical analysis for each sample of the treatment combination $\mathrm{ABC}$ of the factors from each year of research was performed three times.

The aim of this paper is to present a comprehensive statistical analysis, taking into account the three experimental factors A, B, C and the years of research. Our attention is focused primarily on the study of the effect of malt germination time, and the interaction of that factor with cultivars, fertilization and years, on the aforementioned variables. It should be noted that those variables, i.e. the extractivity (\% d.m.) and the malting productivity (\% d.m.) calculated from it, 
represent continuous data and are expressed in percentages to show concentrations of extract of malt and its productivity in relation to dry matter of grain. Such concentrations should not, as a rule, be subjected to any transformation to equalize the variance (see LeClerg et al., 1962). The quality factor $Q$, in turn, is the weighted sum of classes of quality parameters of malt (extractivity and others). It usually attains real values on a scale from 1 (the worst) to 9 (the best); see e.g. Błażewicz et al. (2007).

The statistical analyses, such as analysis of variance and Tukey's HSD test for comparing pairs of means, were performed for the series of years with respect to fixed or random effects of years. Due to the strong differentiation of the years and significant interactions of the factors with years, annual analyses were also carried out. Calculations were performed mainly using the STATISTICA 13 software package.

\section{Data modeling and statistical analysis}

Having regard to the available experimental material, we considered the models of data for a four-factor complete randomized (CR) design with fixed or random effects of years, and a three-factor CR design in annual analyses. We have Model I - fixed model with fixed effects of years and all factors;

Model II - mixed model with random effects of years and fixed effects of all factors.

Model II is more applicable in multi-years experiments. However, in applications Model I is often used. In both cases the models have the same formula

$$
\begin{aligned}
& y_{i j k l m}=\mu+\rho_{i}+\alpha_{j}+(\rho \alpha)_{i j}+\beta_{k}+ \\
& +(\rho \beta)_{i k}+(\alpha \beta)_{j k}+(\rho \alpha \beta)_{i j k}+\gamma_{l}+(\rho \gamma)_{i l}+(\alpha \gamma)_{j l}+ \\
& +(\rho \alpha \gamma)_{i j l}+(\beta \gamma)_{k l}+(\rho \beta \gamma)_{i k l}+(\alpha \beta \gamma)_{j k l}+(\rho \alpha \beta \gamma)_{i j k l}+e_{i j k l m},
\end{aligned}
$$

where $\mu$ is the fixed general mean, $\rho_{i}(i=1,2, \ldots, s)$ is the fixed or random effect of the $i$-th year, $\alpha_{j}(j=1,2, \ldots, a), \beta_{k}(k=1,2, \ldots, b), \gamma_{l}(l=1,2, \ldots, c)$ are the fixed effects of factors $\mathrm{A}, \mathrm{B}, \mathrm{C}$, and other interaction effects are fixed or random accordingly. 
The calculation technique is the same for both models. The difference lies in the assessment of the individual components of variance, and above all in the interpretation of the results and conclusions (see e.g. Elandt, 1964). Practical ways to determine the test functions $F$ are given in section 4 .

After removing in both models the effects of years and the effects of interactions with years, we obtain one model which was used in the annual analyses.

In all of these models the effects of factors A, B, C and all their interaction effects are fixed. Specific cultivars, specific nitrogen fertilization methods and specific germination times are tested. The difference in inference is related to the years. Assuming Model I, we limit inference from the experiment to specific years of research from 2008 to 2010; more precisely, to the environmental conditions occurring in those years. It is worth noting that in practice, researchers are usually interested in selected environments in the analysed years.

In the second model, we assume that among all possible years (whose number is finite) there occur those corresponding to the distribution of meteorological conditions in 2008-2010. Then the years of research may represent a random-like representation (sample) of the entire sequence of possible years (see e.g. Caliński, 1967).

\section{Results and discussion}

Table 2 presents the results of four-way analysis of variance for each variable separately, for both Model I and Model II. It is worth recalling that the Error given in Table 2 for each variable is a pooled error of three respective errors from Table 6 , referring to the analysis of one-year experiments.

The test function F-M I refers to the analysis of Model I (fixed effects of years). It is calculated in the traditional way, by dividing the mean squares (MS) for a given source of variation and for Error. The test function $F$ - $M$ II refers to the analysis of Model II (random effects of years). It is calculated by dividing the mean squares (MS) for a given source of variation and for the corresponding interaction with the years. 
Table 2. Results of four-way ( $D A B C$ ) ANOVA of CR design type for the observed traits

\begin{tabular}{|c|c|c|c|c|c|c|c|c|c|c|}
\hline \multirow{2}{*}{$\begin{array}{l}\text { Source of } \\
\text { variation }\end{array}$} & \multirow[b]{2}{*}{ df } & \multicolumn{3}{|c|}{ Extractivity } & \multicolumn{3}{|c|}{ Productivity } & \multicolumn{3}{|c|}{ Q coefficient } \\
\hline & & MS & $\begin{array}{c}F \\
M I \\
\end{array}$ & $\begin{array}{c}F \\
M I I \\
\end{array}$ & MS & $\begin{array}{c}F \\
M I \\
\end{array}$ & $\begin{array}{c}F \\
M I I \\
\end{array}$ & MS & $\begin{array}{c}F \\
M I\end{array}$ & $\begin{array}{c}F \\
M I I \\
\end{array}$ \\
\hline Years (D) & 2 & 2901.3 & $\begin{array}{c}1421.6 \\
* *\end{array}$ & $\begin{array}{c}1421.6 \\
* *\end{array}$ & 6550.6 & $\begin{array}{c}235.8 \\
* *\end{array}$ & $\begin{array}{c}235.8 \\
* *\end{array}$ & 270.2 & $\begin{array}{c}13829,3 \\
* *\end{array}$ & $\begin{array}{c}13829.3 \\
* *\end{array}$ \\
\hline A-Culti-vars & 1 & 0.18 & 0.09 & 0.02 & 448.2 & $\begin{array}{c}16.1 \\
* *\end{array}$ & 6.14 & 24.7 & $\begin{array}{c}1265.6 \\
* *\end{array}$ & 8.4 \\
\hline $\mathrm{D} \times \mathrm{A}$ & 2 & 9.91 & $\begin{array}{c}4.85 \\
* *\end{array}$ & $\begin{array}{c}4.85 \\
* *\end{array}$ & 72.97 & 2.63 & 2.63 & 2.95 & $\begin{array}{c}151.0 \\
* *\end{array}$ & $\begin{array}{l}151.0 \\
* *\end{array}$ \\
\hline $\begin{array}{l}\text { B-Nitrogen } \\
\text { fertilization }\end{array}$ & 5 & 1.80 & 0.88 & 1.35 & 49.69 & 1.79 & 0.88 & 2.26 & $\begin{array}{c}115.6 \\
* *\end{array}$ & 2.03 \\
\hline $\mathrm{D} \times \mathrm{B}$ & 10 & 1.33 & 0.65 & 0.65 & 56.49 & $\begin{array}{c}2.03 \\
*\end{array}$ & $\begin{array}{c}2.03 \\
*\end{array}$ & 1.11 & $\begin{array}{l}56.85 \\
* *\end{array}$ & $\begin{array}{l}56.85 \\
* *\end{array}$ \\
\hline $\mathrm{A} \times \mathrm{B}$ & 5 & 1.00 & 0.49 & 0.19 & 26.80 & 0.96 & 3.31 & 1.36 & $\begin{array}{c}69.69 \\
* *\end{array}$ & 0.60 \\
\hline $\mathrm{D} \times \mathrm{A} \times \mathrm{B}$ & 10 & 5.19 & $\begin{array}{c}2.54 \\
* * \\
\end{array}$ & $\begin{array}{c}2.54 \\
* * \\
\end{array}$ & 8.10 & 0.29 & 0.29 & 2.27 & $\begin{array}{c}116.0 \\
* * \\
\end{array}$ & $\begin{array}{c}116.0 \\
* * \\
\end{array}$ \\
\hline $\begin{array}{l}\mathrm{C}-\text { Germi- } \\
\text { nation time }\end{array}$ & 3 & 72.91 & $\begin{array}{l}35.72 \\
* *\end{array}$ & 1.58 & 357.7 & $\begin{array}{c}12.9 \\
* *\end{array}$ & 2.22 & 8.11 & $\begin{array}{c}414.79 \\
* *\end{array}$ & 0.98 \\
\hline $\mathrm{D} \times \mathrm{C}$ & 6 & 46.18 & $\begin{array}{c}22.63 \\
* *\end{array}$ & $\begin{array}{c}22.63 \\
* *\end{array}$ & 161.3 & $\begin{array}{c}5.81 \\
* *\end{array}$ & $\begin{array}{l}5.81 \\
* *\end{array}$ & 8.29 & $\begin{array}{c}424.04 \\
* *\end{array}$ & $\begin{array}{c}424.04 \\
* *\end{array}$ \\
\hline $\mathrm{A} \times \mathrm{C}$ & 3 & 3.25 & 1.59 & 1.37 & 14.04 & 0.51 & 0.27 & 0.63 & $\begin{array}{c}32.41 \\
* *\end{array}$ & 0.77 \\
\hline $\mathrm{D} \times \mathrm{A} \times \mathrm{C}$ & 6 & 2.38 & 1.17 & 1.17 & 51.90 & 1.87 & 1.87 & 0.83 & $\begin{array}{c}42.27 \\
* *\end{array}$ & $\begin{array}{l}42.27 \\
* *\end{array}$ \\
\hline $\mathrm{B} \times \mathrm{C}$ & 15 & 1.76 & 0.86 & 0.74 & 27.56 & 0.99 & 1.41 & 0.40 & $\begin{array}{c}20.59 \\
* *\end{array}$ & 0.78 \\
\hline $\mathrm{D} \times \mathrm{B} \times \mathrm{C}$ & 30 & 2.37 & 1.16 & 1.16 & 19.56 & 0.70 & 0.70 & 0.52 & $\begin{array}{c}26.40 \\
* *\end{array}$ & $\begin{array}{l}26.40 \\
* *\end{array}$ \\
\hline $\mathrm{A} \times \mathrm{B} \times \mathrm{C}$ & 15 & 1.14 & 0.56 & 0.98 & 24.43 & 0.88 & 1.22 & 0.68 & $\begin{array}{c}34.63 \\
* *\end{array}$ & 1.67 \\
\hline $\mathrm{D} \times \mathrm{A} \times \mathrm{B} \times \mathrm{C}$ & 30 & 1.17 & 0.57 & 0.57 & 20.10 & 0.72 & 0.72 & 0.41 & $\begin{array}{c}20.74 \\
* *\end{array}$ & $\begin{array}{l}20.74 \\
* *\end{array}$ \\
\hline Error & 288 & 2.04 & & & 27.78 & & & 0.02 & & \\
\hline Total & 431 & & & & & & & & & \\
\hline
\end{tabular}

In Tables 3-5 we describe particular analyses based on Tukey's HSD test, presenting a grouping of the means of the considered traits in the years of the study. 
Table 3. Means of the traits for series of three years (Model I and Model II)

\begin{tabular}{cccc}
\hline Years & $\begin{array}{c}\text { Extractivity } \\
(\% \text { d.m. })\end{array}$ & $\begin{array}{c}\text { Productivity } \\
(\% \text { d.m. })\end{array}$ & Q coefficient \\
\hline 2008 & $78.31^{\mathrm{b}}$ & $71.55^{\mathrm{c}}$ & $5.65^{\mathrm{b}}$ \\
2009 & $82.50^{\mathrm{c}}$ & $67.83^{\mathrm{b}}$ & $7.05^{\mathrm{c}}$ \\
2010 & $73.53^{\mathrm{a}}$ & $58.46^{\mathrm{a}}$ & $4.31^{\mathrm{a}}$ \\
\hline \multicolumn{4}{l}{$\mathrm{a}, \mathrm{b}, \mathrm{c}-$ homogeneous groups $(\alpha=0.01)$}
\end{tabular}

Since the interactions of the factors with years are significant, we also present annual analyses for the considered traits separately, including ANOVA (Table 6) and Tukey's HSD test results for selected groups of means (Tables 7 and 8).

Following the general and particular analyses, we present below the most important conclusions.

\section{For extractivity:}

1. The Tukey's test (see table 3) showed significant differences at $\alpha=0.01$ between years in terms of malt extractivity mean, regardless of other factors. The lowest malt extractivity mean (73.53\% d.m.) was in 2010 (coefficient of variation $-\mathrm{cv}=3.30 \%)$. A significantly higher mean extractivity $(82.50 \%$ d.m.) was recorded in 2009 ( $\mathrm{cv}=0.57 \%$ ). Both extreme means differ significantly from the malt extractivity mean $(78.31 \%$ d.m.) in 2008 $(\mathrm{cv}=2.32 \%)$.

2. Under both models there is a significant interaction of cultivars with years at the level $\alpha=0.01$. Tukey's test (see table 4) showed that the cultivars did not respond equally to the changing weather conditions in each year of testing. The significantly highest mean extractivity for both cultivars (Sebastian $82.46 \%$ d.m., Mauritia $82.54 \%$ d.m.) was obtained in 2009. The significantly lowest mean extractivity for both cultivars (Sebastian $73.26 \%$ d.m., Mauritia $73.80 \%$ d.m.) was obtained in 2010.

3. We may conclude that failure to reject the general hypothesis for the cultivars means that there are no significant differences between Sebastian and Mauritia in terms of the extractivity mean for all possible years (Model II) or for only the years of the study (Model I - see table 4). 
Table 4. Means of the traits for the combination of cultivars and years

\begin{tabular}{ccrrc}
\hline Years & Cultivars & $\begin{array}{c}\text { Extractivity } \\
(\% \text { d.m. })\end{array}$ & $\begin{array}{r}\text { Productivity } \\
(\% \text { d.m. })\end{array}$ & Q coefficient \\
\hline \multirow{2}{*}{2008} & Mauritia & $78.06^{\mathrm{b}}$ & $72.12^{\mathrm{a}}$ & $5.77^{\mathrm{d}}$ \\
& Sebastian & $78.56^{\mathrm{b}}$ & $70.99^{\mathrm{a}}$ & $5.53^{\mathrm{c}}$ \\
\multirow{2}{*}{2009} & Mauritia & $82.54^{\mathrm{c}}$ & $69.67^{\mathrm{a}}$ & $7.25^{\mathrm{f}}$ \\
& Sebastian & $82.46^{\mathrm{c}}$ & $65.99^{\mathrm{a}}$ & $6.85^{\mathrm{e}}$ \\
\multirow{2}{*}{2010} & Mauritia & $73.80^{\mathrm{a}}$ & $59.12^{\mathrm{a}}$ & $4.71^{\mathrm{b}}$ \\
& Sebastian & $73.26^{\mathrm{a}}$ & $57.81^{\mathrm{a}}$ & $3.91^{\mathrm{a}}$ \\
\hline
\end{tabular}

$\mathrm{a}, \mathrm{b}, \ldots$ - homogeneous groups $(\alpha=0.01)$

4. There a highly significant interaction of malt germination time with years ( $\alpha$ $=0.01$ ) was found. For each germination time separately, the extractivity mean varied significantly in each year of the study, the lowest always being in 2010, and the highest in 2009 (see table 5).

Table 5. Means of the traits for the combination of germination time and years

\begin{tabular}{ccccr}
\hline Years & $\begin{array}{c}\text { Germination } \\
\text { time of malt } \\
\text { (days) }\end{array}$ & $\begin{array}{c}\text { Extractivity } \\
(\% \text { d.m. })\end{array}$ & $\begin{array}{c}\text { Productivity } \\
(\% \text { d.m. })\end{array}$ & $\begin{array}{c}\text { Q } \\
\text { coefficient }\end{array}$ \\
\hline \multirow{4}{*}{2008} & 3 & $77.52^{\mathrm{d}}$ & $70.68^{\mathrm{ef}}$ & $5.10^{\mathrm{d}}$ \\
& 4 & $78.69^{\mathrm{de}}$ & $71.25^{\mathrm{ef}}$ & $6.09^{\mathrm{e}}$ \\
& 5 & $77.76^{\mathrm{d}}$ & $71.34^{\mathrm{ef}}$ & $5.02^{\mathrm{d}}$ \\
& 6 & $79.27^{\mathrm{e}}$ & $72.94^{\mathrm{f}}$ & $6.39^{\mathrm{f}}$ \\
& 3 & $82.44^{\mathrm{f}}$ & $64.41^{\mathrm{cd}}$ & $6.87^{\mathrm{h}}$ \\
& 4 & $82.29^{\mathrm{f}}$ & $67.95^{\mathrm{de}}$ & $6.52^{\mathrm{g}}$ \\
& 5 & $82.52^{\mathrm{f}}$ & $68.25^{\mathrm{de}}$ & $7.48^{\mathrm{j}}$ \\
& 6 & $82.74^{\mathrm{f}}$ & $70.73^{\mathrm{ef}}$ & $7.33^{\mathrm{i}}$ \\
& 3 & $70.78^{\mathrm{a}}$ & $59.85^{\mathrm{bc}}$ & $4.20^{\mathrm{a}}$ \\
& 4 & $75.27^{\mathrm{c}}$ & $54.02^{\mathrm{a}}$ & $4.28^{\mathrm{ab}}$ \\
& 5 & $74.58^{\mathrm{bc}}$ & $58.08^{\mathrm{ab}}$ & $4.35^{\mathrm{bc}}$ \\
& 6 & $73.49^{\mathrm{b}}$ & $61.90^{\mathrm{bc}}$ & $4.42^{\mathrm{c}}$ \\
\hline
\end{tabular}

$a, b, \ldots-$ homogeneous groups $(\alpha=0.01)$

5. Due to the interaction of nitrogen fertilization with years, one-year models were considered. In not all years of the study, fertilization was significant (Table 7). 
Table 6. Mean squares in annual analyses of variance

\begin{tabular}{|c|c|c|c|c|c|c|c|c|c|c|}
\hline \multirow{2}{*}{$\begin{array}{c}\text { Source } \\
\text { of variation }\end{array}$} & \multirow{2}{*}{ df } & \multicolumn{3}{|c|}{ Extractivity (\% d.m.) } & \multicolumn{3}{|c|}{ Productivity (\% d.m.) } & \multicolumn{3}{|c|}{ Q coefficient } \\
\hline & & 2008 & 2009 & 2010 & 2008 & 2009 & 2010 & 2008 & 2009 & 2010 \\
\hline A-Cultivars & 1 & $\begin{array}{c}9.05 \\
*\end{array}$ & 0.21 & 10.73 & $\begin{array}{c}45.79 \\
* *\end{array}$ & $\begin{array}{c}486.94 \\
* *\end{array}$ & 61.36 & $\begin{array}{c}2.07 \\
* *\end{array}$ & $\begin{array}{c}5.76 \\
* *\end{array}$ & $\begin{array}{c}22.80 \\
* *\end{array}$ \\
\hline $\begin{array}{l}\text { B-Nitrogen } \\
\text { fertilization }\end{array}$ & 5 & 3.29 & 0.15 & 1.03 & $\begin{array}{c}11.44 \\
*\end{array}$ & $\begin{array}{c}131.68 \\
* *\end{array}$ & 19.56 & $\begin{array}{c}3.24 \\
* *\end{array}$ & $\begin{array}{l}1.02 \\
* *\end{array}$ & $\begin{array}{c}0.22 \\
* *\end{array}$ \\
\hline $\mathrm{A} \times \mathrm{B}$ & 5 & $\begin{array}{c}8.11 \\
* *\end{array}$ & $\begin{array}{c}0.61 \\
* *\end{array}$ & 2.65 & $\begin{array}{c}15.80 \\
* *\end{array}$ & 13.46 & 13.74 & $\begin{array}{c}3.12 \\
* *\end{array}$ & $\begin{array}{c}2.54 \\
* *\end{array}$ & $\begin{array}{c}0.24 \\
* *\end{array}$ \\
\hline $\begin{array}{c}\mathrm{C}-\text { Germination } \\
\text { time }\end{array}$ & 3 & $\begin{array}{c}24.16 \\
* *\end{array}$ & $\begin{array}{l}1.25 \\
* *\end{array}$ & $\begin{array}{c}139.85 \\
* *\end{array}$ & $\begin{array}{c}33.79 \\
* *\end{array}$ & $\begin{array}{c}243.56 \\
* *\end{array}$ & $\begin{array}{c}402.9 \\
* *\end{array}$ & $\begin{array}{c}17.33 \\
* *\end{array}$ & $\begin{array}{l}7.03 \\
* *\end{array}$ & $\begin{array}{c}0.32 \\
* *\end{array}$ \\
\hline $\mathrm{A} \times \mathrm{C}$ & 3 & $\begin{array}{c}6.12 \\
*\end{array}$ & 0.05 & 1.86 & $\begin{array}{l}17.75 \\
*\end{array}$ & 25.02 & 75.06 & $\begin{array}{c}1.29 \\
* *\end{array}$ & $\begin{array}{c}0.88 \\
* *\end{array}$ & $\begin{array}{c}0.12 \\
* *\end{array}$ \\
\hline $\mathrm{B} \times \mathrm{C}$ & 15 & $\begin{array}{l}5.29 \\
* *\end{array}$ & $\begin{array}{c}0.33 \\
*\end{array}$ & 0.89 & 4.04 & $\begin{array}{l}47.08 \\
* *\end{array}$ & 15.55 & $\begin{array}{c}0.59 \\
* *\end{array}$ & $\begin{array}{c}0.81 \\
* *\end{array}$ & $\begin{array}{c}0.03 \\
*\end{array}$ \\
\hline $\mathrm{A} \times \mathrm{B} \times \mathrm{C}$ & 15 & 2.26 & 0.14 & 1.07 & 5.46 & $\begin{array}{c}32.03 \\
* *\end{array}$ & 27.14 & $\begin{array}{c}0.32 \\
* *\end{array}$ & $\begin{array}{c}1.12 \\
* *\end{array}$ & $\begin{array}{c}0.04 \\
* *\end{array}$ \\
\hline Error & 96 & 2.19 & 0.18 & 3.76 & 4.89 & 14.11 & 64.34 & 0.03 & 0.02 & 0.02 \\
\hline Total & 143 & & & & & & & & & \\
\hline
\end{tabular}

Table 7. Means of the nitrogen fertilization in each year separately

\begin{tabular}{ccrrr}
\hline Years & $\begin{array}{c}\text { Nitrogen } \\
\text { fertilization }\end{array}$ & $\begin{array}{c}\text { Extractivity } \\
(\% \text { d.m. })\end{array}$ & $\begin{array}{c}\text { Productivity } \\
(\% \text { d.m. })\end{array}$ & $\begin{array}{c}\text { Q } \\
\text { coefficient }\end{array}$ \\
\hline \multirow{3}{*}{2008} & 0 & $78.67^{\mathrm{a}}$ & $72.18^{\mathrm{b}}$ & $5.68^{\mathrm{b}}$ \\
& 20 & $78.55^{\mathrm{a}}$ & $71.44^{\mathrm{ab}}$ & $5.67^{\mathrm{b}}$ \\
& 40 & $78.29^{\mathrm{a}}$ & $72.00^{\mathrm{ab}}$ & $5.98^{\mathrm{c}}$ \\
& 60 & $78.53^{\mathrm{a}}$ & $71.89^{\mathrm{ab}}$ & $6.11^{\mathrm{c}}$ \\
& $60(40+20 \mathrm{I})$ & $78.15^{\mathrm{a}}$ & $71.54^{\mathrm{ab}}$ & $5.20^{\mathrm{a}}$ \\
& $60(40+20 \mathrm{II})$ & $77.66^{\mathrm{a}}$ & $70.26^{\mathrm{a}}$ & $5.26^{\mathrm{a}}$ \\
\hline \multirow{4}{*}{2009} & 0 & $82.63^{\mathrm{a}}$ & $71.48^{\mathrm{c}}$ & $7.09^{\mathrm{c}}$ \\
& 20 & $82.43^{\mathrm{a}}$ & $69.57^{\mathrm{bc}}$ & $7.31^{\mathrm{d}}$ \\
& 40 & $82.49^{\mathrm{a}}$ & $68.16^{\mathrm{abc}}$ & $7.26^{\mathrm{d}}$ \\
& 60 & $82.40^{\mathrm{a}}$ & $65.96^{\mathrm{ab}}$ & $6.81^{\mathrm{a}}$ \\
& $60(40+20 \mathrm{I})$ & $82.50^{\mathrm{a}}$ & $65.67^{\mathrm{a}}$ & $6.95^{\mathrm{b}}$ \\
& $60(40+20 \mathrm{II})$ & $82.54^{\mathrm{a}}$ & $66.16^{\mathrm{ab}}$ & $6.88^{\mathrm{ab}}$ \\
\hline \multirow{4}{*}{2010} & 0 & $73.53^{\mathrm{a}}$ & $58.10^{\mathrm{a}}$ & $4.29^{\mathrm{ab}}$ \\
& 20 & $73.78^{\mathrm{a}}$ & $56.93^{\mathrm{a}}$ & $4.28^{\mathrm{ab}}$ \\
& 40 & $73.52^{\mathrm{a}}$ & $59.47^{\mathrm{a}}$ & $4.39^{\mathrm{bc}}$ \\
& 60 & $73.28^{\mathrm{a}}$ & $58.51^{\mathrm{a}}$ & $4.46^{\mathrm{c}}$ \\
& $60(40+20 \mathrm{I})$ & $73.73^{\mathrm{a}}$ & $59.23^{\mathrm{a}}$ & $4.24^{\mathrm{a}}$ \\
& $60(40+20 \mathrm{II})$ & $73.32^{\mathrm{a}}$ & $58.54^{\mathrm{a}}$ & $4.21^{\mathrm{a}}$ \\
\hline
\end{tabular}

$\mathrm{a}, \mathrm{b}, \mathrm{c}-$ homogeneous groups $(\alpha=0.01)$ 


\section{For malting productivity:}

1. The Tukey's test (see table 3) showed significant differences at $\alpha=0.01$ between the years in terms of malt productivity mean, regardless of other factors. The lowest mean malt productivity $(58.46 \%$ d.m.) was recorded in $2010(\mathrm{cv}=13.17 \%)$. A significantly higher productivity mean $(71.55 \%$ d.m. $)$ was obtained in $2008(\mathrm{cv}=3.60 \%)$. Both extreme means differ significantly from the mean productivity $(67.83 \%$ d.m.) in 2009 ( $\mathrm{cv}=8.32 \%)$.

2. Under considered models there is no significant interaction of the cultivars with years at the level $\alpha=0.01$ (see table 2). This means that the differences between the cultivars Sebastian and Mauritia with respect to productivity mean do not depend on the years 2008-2010 under Model I or all possible years under Model II. Each year, we can expect the same differences between these cultivars with respect to productivity mean.

3. There a highly significant interaction of the germination time of malt with years $(\alpha=0.01)$ was found (see Table 2$)$. We may conclude that in all possible years, the number of days of malt germination differently affects the malting productivity.

4. If we refer to the years $2008-2010$ only, the malt germination time proved to be important for productivity in each year, regardless of other factors. Tukey's test (see table 5) showed at a significance level of $\alpha=0.01$ that 6 day malts (regardless of other factors) had a significantly higher productivity mean than some others.

\section{For the $Q$ coefficient:}

1. Under Model I, all general hypotheses at the level of $\alpha=0.01$ were rejected (see table 2).

2. The Tukey's test showed at a level of $\alpha=0.01$ (see table 3) significant differences between the mean $\mathrm{Q}$ coefficient for years, regardless of other factors. In the study years the significantly lowest mean value of Q $(4.31 \%)$ was in $2010(\mathrm{cv}=10.44 \%)$, and the significantly highest mean $(7.05 \%)$ in $2009(\mathrm{cv}=10.47 \%)$. 
Table 8. Means of the combination of cultivars with germination time of malt in each year separately

\begin{tabular}{|c|c|c|c|c|c|}
\hline Years & Cultivars & $\begin{array}{c}\text { Germination } \\
\text { time of malt } \\
\text { (days) }\end{array}$ & $\begin{array}{l}\text { Extractivity } \\
\text { (\% d.m.) }\end{array}$ & $\begin{array}{l}\text { Productivity } \\
\text { (\% d.m.) }\end{array}$ & $\begin{array}{c}\mathrm{Q} \\
\text { coefficient }\end{array}$ \\
\hline \multirow{8}{*}{2008} & \multirow[t]{2}{*}{ Mauritia } & 3 & $77.59^{\mathrm{abc}}$ & $71.66^{\mathrm{abc}}$ & $5.23^{\mathrm{c}}$ \\
\hline & & 4 & $78.42^{\mathrm{abcd}}$ & $72.20^{\mathrm{bc}}$ & $6.25^{\mathrm{e}}$ \\
\hline & \multirow{6}{*}{ Sebastian } & 5 & $76.93^{a}$ & $70.86^{\mathrm{ab}}$ & $4.88^{\mathrm{a}}$ \\
\hline & & 6 & $79.29^{\mathrm{d}}$ & $73.74^{c}$ & $6.71^{\mathrm{f}}$ \\
\hline & & 3 & $77.44^{\mathrm{ab}}$ & $69.70^{\mathrm{a}}$ & $4.97^{\mathrm{ab}}$ \\
\hline & & 4 & $78.97^{\mathrm{cd}}$ & $70.29^{\mathrm{ab}}$ & $5.93^{\mathrm{d}}$ \\
\hline & & 5 & $78.58^{\mathrm{bcd}}$ & $71.83^{\mathrm{abc}}$ & $5.15^{\mathrm{bc}}$ \\
\hline & & 6 & $79.26^{\mathrm{d}}$ & $72.13^{\mathrm{bc}}$ & $6.07^{\mathrm{de}}$ \\
\hline \multirow{8}{*}{2009} & \multirow[t]{2}{*}{ Mauritia } & 3 & $82.46^{\mathrm{a}}$ & $66.74^{\mathrm{a}}$ & $6.97^{\mathrm{c}}$ \\
\hline & & 4 & $82.32^{\mathrm{a}}$ & $70.67^{\mathrm{a}}$ & $6.95^{\mathrm{c}}$ \\
\hline & \multirow{6}{*}{ Sebastian } & 5 & $82.61^{\mathrm{a}}$ & $69.63^{a}$ & $7.62^{\mathrm{f}}$ \\
\hline & & 6 & $82.77^{a}$ & $71.64^{\mathrm{a}}$ & $7.47^{\mathrm{ef}}$ \\
\hline & & 3 & $82.43^{\mathrm{a}}$ & $62.07^{\mathrm{a}}$ & $6.77^{\mathrm{b}}$ \\
\hline & & 4 & $82.27^{\mathrm{a}}$ & $65.23^{\mathrm{a}}$ & $6.08^{\mathrm{a}}$ \\
\hline & & 5 & $82.43^{\mathrm{a}}$ & $66.86^{\mathrm{a}}$ & $7.35^{\mathrm{de}}$ \\
\hline & & 6 & $82.72^{\mathrm{a}}$ & $69.81^{\mathrm{a}}$ & $7.20^{\mathrm{d}}$ \\
\hline \multirow{8}{*}{2010} & \multirow[t]{2}{*}{ Mauritia } & 3 & $71.36^{\mathrm{a}}$ & $59.31^{\mathrm{a}}$ & $4.67^{\mathrm{d}}$ \\
\hline & & 4 & $75.58^{\mathrm{a}}$ & $54.49^{\mathrm{a}}$ & $4.65^{\mathrm{d}}$ \\
\hline & \multirow{6}{*}{ Sebastian } & 5 & $74.71^{\mathrm{a}}$ & $60.81^{\mathrm{a}}$ & $4.77^{\mathrm{d}}$ \\
\hline & & 6 & $73.56^{\mathrm{a}}$ & $61.85^{\mathrm{a}}$ & $4.75^{\mathrm{d}}$ \\
\hline & & 3 & $70.21^{\mathrm{a}}$ & $60.39^{a}$ & $3.73^{\mathrm{a}}$ \\
\hline & & 4 & $74.96^{\mathrm{a}}$ & $53.55^{\mathrm{a}}$ & $3.90^{\mathrm{b}}$ \\
\hline & & 5 & $74.44^{\mathrm{a}}$ & $55.36^{\mathrm{a}}$ & $3.93^{\mathrm{bc}}$ \\
\hline & & 6 & $73.42^{\mathrm{a}}$ & $61.94^{\mathrm{a}}$ & $4.08^{c}$ \\
\hline
\end{tabular}

$\mathrm{a}, \mathrm{b}, \ldots-$ homogeneous groups $(\alpha=0.01)$

3. There is a significant interaction of cultivars with years at the level $\alpha=0.01$ (see Table 4). The cultivars did not respond equally to the changing weather conditions in each year of the study. Under Model I, it was shown that the mean Q coefficient for each of the tested cultivars changed significantly depending on the year of the study. The lowest was in 2010, and the highest in 2009 . 
4. Under Model I only, Tukey's test showed (see Table 5) that the significantly different mean Q coefficient was obtained for 3-day malt, regardless of other factors, than for 6-day malt.

5. Under Model I only, considering the interaction of the cultivars and germination time, it was shown that for both Mauritia and Sebastian the 3day malts had the significantly lowest mean $Q$ value, and the 6-day-old malts the highest. Under Model II, non-rejection of the hypothesis relating to germination time means that there are no significant differences between germination time in terms of the mean values of the quality coefficient from all possible years, not only the years of the study.

\section{Conclusion}

1. We focused on two models with malt observation in four-way experiments, in which fixed or random effects of years were taken into account.

2. The choice of the model depends on the available experimental material and the extent to which conclusions can be formulated.

3. Adopting the model with random effects of years in the analysis of the experiment, we obtain a broader perspective in inference than with the model limiting the conclusions to the years of the study.

4. The results of the analysis show that the most decisive factor for the qualitative characteristics of grain and malts is the weather conditions for all possible years. In the years of the study, 2010 had the least favorable conditions for obtaining grain and malts with good parameters, while 2009 had the best.

5. Extending the germination time of the grain to 6 days contributes to an increase in the value of the $\mathrm{Q}$ coefficient in all possible years.

6. In the years of the study, the Sebastian cultivar had a lower mean value of the $\mathrm{Q}$ coefficient than the Mauritia cultivar. 


\section{REFERENCES}

Ambroży K., Mejza I. (2012): Modeling data from three-factor experiments with split units set up in designs with different block structures (in Polish). Biul. IHAR 264: 23 31.

Błażewicz J., Liszewski M. (2003): Ziarno jęczmienia nagiego odmiany 'Rastik' jako surowiec do produkcji słodów typu pilzneńskiego. Technologia Alimentaria 2(1): 63-74.

Błażewicz J., Liszewski M., Zembold-Guła A. (2007): Usability of Bishop formula in evaluation of malting quality of barley grain. Pol. J. Food Nutr. Sci. 57 4(A): 37-40.

Błażewicz J., Liszewski M., Zembold-Guła A., Kozłowska K., Szwed Ł. (2013): Liczba Kolbacza jako ważny wskaźnik wartości przetwórczej ziarna jęczmienia browarnego. Fragmenta Agronomica 30(3): 46-53.

Błażewicz J., Zembold-Guła A., Żarski J., Dudek S., Kuśmierek-Tomaszewska R. (2011): Wpływ deszczowania i nawożenia azotem w technologii uprawy jęczmienia browarnego na wydajność procesu słodowania - Wstępne wyniki badań. Infrastructure and Ecology of Rural Areas 6/2011: 109-117.

Bocianowski J., Nowosad K. (2015): Mixed linear model approaches in mapping QTLs with epistatic effects by a simulation study. Euphytica 202: 459-467.

Caliński T. (1967): Doświadczenia wielokrotne i wieloletnie (in Polish). In: Training Materials of the Research Centre for Cultivar Testing, Part 1 - Basic problems of agricultural experimentation, Słupia Wielka, 1967.

Caliński T., Krzyśko M., Wołyński W. (2006): Multivariate analysis. A comparison of some tests for determining the number of nonzero canonical correlations. Communications in Statistics - Simulation and Computation 35: 727-749.

Elandt R. (1964): Statystyka matematyczna w zastosowaniu do doświadczalnictwa rolniczego (in Polish). PWN, Warsaw 1964.

LeClerg E.L., Leonard W.H., Clark A.G. (1962): Field plot technique. Burgess, Minneapolis.

Liszewski M., Błażewicz J., Zembold-Guła A., Szwed Ł., Kozłowska K. (2012): Wpływ sposobu nawożenia azotem na ekstraktywność słodu jęczmiennego. Fragmenta Agronomica 29(1): 93-104.

Mejza I. (1999): Design and analysis of series of two factorial experiments with split units (in Polish). Roczniki AR w Poznaniu, z. 301. 